\title{
AN ANALYSIS OF BLOOD USAGE IN AN ELECTIVE SURGERIES AND ITS WASTAGE AT MEDICAL COLLEGE HOSPITAL
}

Nagarekha Kulkarni.

1. Associate Professor, Department of Pathology, Vijayanagara Institute of Medical Sciences, Bellary, Karnataka.

\section{CORRESPONDING AUTHOR}

Dr. Nagarekha Kulkarni, Associate Professor, Vijayanagara Institute of Medical Sciences, E-mail: nagarekha1970@gmail.com,

Ph: 00919449463366.

ABSTRACT: BACKGROUND: The demand for large quantities of blood for elective surgeries, of which little is utilized results in exhaustion of valuable supplies and resources both in terms of technician time and reagents. This adds to the financial burden of the patients. The aim of this study is to analyse the usage of blood in elective surgeries and to prevent excessive wastage of blood. METHODS:_A retrospective study was conducted at Medical College Hospital Blood Bank during the period from January 2010 to December 2010.The number of patients cross-matched $\&$ transfused were analysed. The different transfusion indices such as Cross match/Transfusion ratio(C/T), Transfusion Probability (\%T), Transfusion Index (TI) were calculated. Maximal Surgical Blood Ordering System (MSBOS) was estimated for each procedure and the degree of over transfusion was calculated. RESULTS: A total of 1276 units of blood were cross-matched for 804 patients, but only 399 units were transfused to 213 patients i.e. $26 \%$ of blood crossmatched was utilized, leaving $74 \%$ unutilized. Significant blood utilization was nil in most of the routine elective cases. The overall C/T was 2.01, MSBOS was 0.465 and in $26 \%$ of cases over transfusion was present. CONCLUSION: This study showed that there was excessive cross matching of blood. "Type, screen and hold" policy should be implemented. Blood ordering pattern needs to be revised and over-ordering of blood should be minimized.

KEY WORDS: elective surgeries, transfusion indices, over transfusion

INTRODUCTION: The optimal function of the surgical departments depends on an efficient round the clock blood dispensing service of the blood bank.[1] Blood transfusion will be liberal with the ready availability of the blood and blood components. Many units of blood routinely ordered by the surgeons are not utilized, but are held in reserve and are thus unavailable for the needy patient. [2] The consequences of such misuse leads to outdating of blood, overburdening on blood bank personnel, depletion of blood bank resources, and wastage of blood.[3] In South Africa for example, $7-10 \%$ of blood is wasted annually because of over-ordering of blood. ${ }^{[4]}$ It has become clear from the studies of United States, Australia and Israel that great savings may be made from rationalizing blood ordering habits.[5] Hence it is quiet necessary to streamline the blood usage by incorporating blood ordering schedule for such procedures which decreases over-ordering of blood, unnecessary compatibility testing, returning of unused blood \& wastage due to outdating.

A maximum surgical blood order schedule (MSBOS) provides guidelines for frequently performed elective surgical procedures by recommending the maximum number of units of blood to be cross matched preoperatively. The MSBOS has the following advantages [6]:

Journal of Evolution of Medical and Dental Sciences/Volume1/Issue5/November-2012Page-652 
1. A reduction in cross matching work load of the blood transfusion laboratory (in some cases in excess of 20\%) which allows more time to respond to emergency requests, and also to investigate complex serological problems.

2. A reduction in the level of stress.

3. More efficient use of blood stocks and a reduction in wastage due to out-dating.

The ratio of the number of units cross matched to the number of units actually transfused, that is C: T ratio, T ratio should not exceed 2:1. Although MSBOS has improved the efficiency of blood utilization, there are certain drawbacks, the most significant are being the absence of accountability for individual, differences in transfusion requirements between different persons undergoing the same surgical procedure..$^{[3]}$

The aim of this study is to analyse the usage of blood in elective surgeries and to study the measures to prevent excessive wastage of blood bank resources .

MATERIALS AND METHODS: A retrospective study was conducted at Medical College Hospital Blood Bank during the period from January 2010 to December 2010. There are seven surgical departments which include Obstetrics \& Gynaecology, Surgery, Orthopaedic Surgery, Urology, Neurosurgery, ENT and Ophthalmolgy and perform between 7500- 8000 elective surgeries a year. The patients included in this study are adult patients who underwent elective surgical procedures for which requisition of blood was made. Postponed elective surgeries for various reasons and patients who underwent massive transfusion were excluded from the study to eliminate bias.(Massive transfusion is defined based on the absolute number of transfused packed red blood cells (RBCs) either the transfusion of 10 units or more of packed RBCs in 24 hours or the transfusion of 20 units of packed RBC or more in the course of the hospital stay).[3] The details of the patient who underwent elective surgical procedures was obtained from the operation theatre records. The number of units cross matched, the number of units issued and transfused during the procedure were obtained from blood bank records. The pre-operative haemoglobin $(\mathrm{Hb})$ levels, the post-operative $\mathrm{Hb}$ levels of patient between first and fourth postoperative days were recorded The following transfusion indices were used to determine the blood utilization for each surgical procedure.[5]

A) CROSS-MATCH TO TRANSFUSION RATIO (C/T RATIO)= No. of units crossmatched /No. of units transfused

A ratio of $<2.5$ is considered indicative of significant blood usage.

B) TRANSFUSION PROBABILITY (\%T) = No. of patients transfused x100 /No. of patients cross-matched.

A value of $>30$ was considered indicative of significant blood usage.

C) TRANSFUSION INDEX (TI)= No. of units transfused /No. of patients crossmatched

A value of $>0.5$ was considered indicative of significant blood utilization.

Next Maximal Surgical Blood Order Schedule (MSBOS) and degree of over transfusion was calculated by using the following formula:

\section{1. $\operatorname{MSBOS}=1.5 \times \mathrm{xti}$}

MSBOS estimates the amount of blood that will be needed for the individual procedure.

2. DEGREE OF OVERTRANSFUSION= No. of patients with post-transfusion $\mathrm{Hb}$ more than $11 \mathrm{~g} / \mathrm{dl} /$ Total no. of patients transfused

Journal of Evolution of Medical and Dental Sciences/Volume1/Issue5/November-2012Page-653 
RESULTS: The patients who had elective surgeries for which request for blood (packed red cell concentrate) was made from six surgical departments, except ophthalmology. Total number of patients included were 804 . Male patients were 228, while female were 576.The age range was 15-65 years. The mean pre-operative $\mathrm{Hb}$ in the study group was $10.2+/-0.8 \mathrm{~g} / \mathrm{dl}$. On calculation of all the transfusion indices, a total of 1276 units of blood were cross-matched for 804 patients, but only 399 units were transfused to 213 patients i.e;26\% of blood cross-matched was utilized, leaving 74\% unutilized. The overall C/T was 2.01 (as shown in Table- 1). Maximum number of patients (61\%) who had requested for blood was from the department of obstetrics \& gynaecology with $47 \%$ listed for LSCS and 53\% being gynaecology cases. The department of Surgery, Orthopaedic, Urology, Neurosurgery, ENT recorded 14\%, 12\%, 10\%, 2\%, 1\% respectively.

1.OBSTETRICS AND GYNAECOLOGY: The blood usage indices for obstetrics \& gynaecology cases (as shown in Table-2). LSCS (general) was the most frequently performed elective surgery(190 cases) and had the highest total number of units cross-matched (272cases).All the three transfusion indices $(\mathrm{C} / \mathrm{T}, \% \mathrm{~T}, \mathrm{TI})$ showed less utilization of blood. In LSCS-placenta praevia all the 3 indices showed significant utilization and MSBOS is more in this procedure. In dilatation and curettage (D\&C) and total abdominal hysterectomy \& bilateral salphingooopherectomy (TAHBS), two indices showed blood utilization. The C/T ratio was significant in LSCS-placenta praevia and vaginal hysterectomy.

2. GENERAL SURGERY: Blood usage for surgical cases (as shown in Table-3). Modified radical mastectomy was the most frequently performed elective surgery (26cases) and had the highest total number of units cross-matched (32 units).The C/T and TI was significant. All the transfusion indices were nil in patients who have undergone laparoscopic cholecystectomy, thyroidectomy and oesophagectomy. Blood utilization was more in right hemicolectomy. In large bowel resection 2 indices were significant. But \%T was high in open cholecystectomy and spleenectomy. In breast mass lumpectomy $\mathrm{C} / \mathrm{T}$ was high and other indices were insignificant indicating less utilization of blood. MSOBS was more in large bowel resection.

3. ORTHOPAEDICS: Blood usage for orthopaedic surgical cases (as shown in Table-4). All the three transfusion indices were significant in hemiarthroplasty, disc surgery, tibial fractures and total hip replacement indicating more blood utilization. In trochantric fracture and shoulder repair, all the three transfusion indices were nil, because number of units transfused was nil. In femur shaft fracture C/T was high and \%T \&TI was insignificant. MSBOS in tibial fractures was more.

4. UROLOGY: Blood usage for urology cases (as shown in Table-5). Transurethral resection of prostate (TURP) was the most frequently performed elective surgery and the three transfusion indices was nil. In nephrectomy and radical cystectomy the three indices showed significant blood utilization and MSBOS in nephrectomy was more.

5. NEUROSURGERY: Blood usage for neurosurgery cases (as shown in Table-6). Craniotomy was the only one elective surgery performed and requested for blood. Fifty units of blood were cross matched for eighteen patients. All the three indices were significant.

Journal of Evolution of Medical and Dental Sciences/Volume1/Issue5/November-2012Page-654 
6. ENT: Blood utilization was nil (as shown in Table-7), because no patient received blood transfusion.

The overall MSBOS was 0.465 .Among 804 cases, we were able to trace 121 cases who had been transfused with red cells with in 24 hours of surgery and had documented posttransfusion Hb levels. Using the formula stated above, 32 (26\%) cases of the patient has been over transfused and may be the cause of low $\mathrm{C} / \mathrm{T}$ ratio.

DISCUSSION: Blood is a precious commodity and its proper utilization is the key for efficient management of blood bank resources. Blood transfusion no doubt plays a major role in the resuscitation and management of surgical patients, but surgeons most of the time overestimate the anticipated blood loss thereby over-ordering blood.[7] Many a times blood requisition is made by 'force of habit'. Analysis of the data indicated that the majority (77\%) of operations will need no pre-operative preparations of blood.[8] The demand for large quantity of blood for elective surgeries of which little is utilized causes wastage of valuable supplies and resources both in terms of technician time and reagents. Hence it is essential that the usage of blood and blood product be rationalized and in crisis situations only.

A number of studies in many countries of the world have shown over-ordering of blood by surgeons with utilization ranging from 5-40\%. [9] Basnet et al [2] showed $13.6 \%$ of utilization. Present study showed $26 \%$ of cross matched blood being utilized. This suggests that a significant amount of time spent by overworked blood bank technicians as well as reagents used for cross matching were wasted. In our study significant blood utilization using all three indices was obtained in placenta praevia, right hemicolectomy, hemiarthroplasty, disc surgery, tibial fractures, total hip replacement, nephrectomy, radical cystectomy and craniotomy. Various published studies elsewhere have shown similar findings. ${ }^{[4,10]}$ The study also shown that in ENT surgeries, laparoscopic cholecystectomy, thyroidectomy, oesophagectomy, trochantric fracture, shoulder repair, TURP, none of the blood that was cross matched was utilized which was similar to the findings of Olawuni Ho et al.[4] This indicates that the routine cross matching of blood in elective surgery is a culture rather than a necessity.[11] The lack of confidence on the part of surgeons in the ability of the blood bank staff to supply blood immediately if required.[12] The ordering of blood appeared to be even more indiscriminate. The ordering of blood for surgery was left to the inexperienced house surgeons who have been known to over order blood due to lack of communication with the senior doctors.[13]

In the present study, pre-operative cross matching for elective surgery was 1276 units for 804 patients. The overall $\mathrm{C} / \mathrm{T}$ ratio was 2.015 . A low $\mathrm{C} / \mathrm{T}$ ratio may represent a low cross match incidence or alternatively a high transfusion incidence conversely, a high $\mathrm{C} / \mathrm{T}$ may represent a high cross match incidence or low transfusion incidence.[14] In the authors study the overall C/T ratio showed 4.4, which represents only about one fifth of the blood cross matched for elective surgery is transfused.[1] In order to reduce excessive cross-matching "type, screen and hold" procedure must be implemented. Here, blood is screened for antibodies by using internationally accepted techniques and reagents a few days prior to the procedure. If no antibodies are detected, no blood will be cross-matched. If need does arise for transfusion, cross matching may be accomplished in 10 minutes using the immediate spin method. If antibodies are detected in the antibody screening tests, suitable blood units lacking the corresponding antigen and compatible with the patient will have to be provided prior to surgery. Several studies have shown the "type, screen \& hold" to be safe if done according

Journal of Evolution of Medical and Dental Sciences/Volume1/Issue5/November-2012Page-655 
recommended technique.[15] This technique proved to be $99.99 \%$ efficient in preventing incompatible blood.[10]

The degree of over transfusion obtained here is similar as compared to that of various other centers, where over transfusion ranged from $27 \%$ to $39 \%{ }^{[13]}$ Dodsworth[16] found 33\% and Maha SA[1] found $45.5 \%$. This study suggests that blood has been further wasted and patient have been unnecessarily exposed to the very significant risk of blood transfusion.

In the present study MSBOS in placenta praevia, nephrectomy and craniotomy was high. But the overall MSBOS is 0.465 . In a similar study by Vibhute [9] the blood evaluation and transfusion practices for 500 elective general surgical procedures were evaluated and MSBOS was put into immediate effect after formulation. As a result, the blood ordering pattern changed for the next 150 patients. ${ }^{[9]}$ This shows that MSBOS definitely improves the blood utilization and reduces the wastage rate. However, it does not take into consideration the individual differences in transfusion needs between different patients undergoing the same surgery. Surgical blood ordering equation (SBOE) is an extended MSBOS incorporating patient and surgical variables, such as pre- and postoperative hemoglobin levels of the patient and the amount of surgical blood loss during each surgical procedure.[3] By establishing such an SBOE, each surgical team can develop its own transfusion system. They can also audit the operative blood loss for each procedure.[10] A strong institutional hospital transfusion committee is required to uplift the profile of blood transfusion.

CONCLUSION: The present study showed $26 \%$ of cross matched blood being utilized. The overall C/T ratio is 2.015 and the over transfusion is $26 \%$. Blood ordering pattern needs to be revised and over-ordering of blood should be minimized. It is an ideal method in saving hospital resources and manpower. In order to reduce unnecessary cross matching, "type, screen and hold" procedure must be implemented. However, one must confirm the availability of blood for emergency situation before starting the surgery.

\section{ACKNOWLEDGEMENT:}

I thank the Director, VIMS, Professor and HOD, Department of Pathology, VIMS for kind co-operation and I thank all the surgeons, blood bank staff for their help.

\section{REFERENCES:}

1. Maha SA, Abdelhadi, Layla AM, Bashawari. Blood conservation in elective surgery. Kuwait Medical Journal. 2001; 33(3):232-234.

2. Basnet RB, Lamichhane D, Sharma VK. A study of blood requisition and transfusion practice in surgery at Bir Hospital. PMJN. July-Dec 2009; 9(2):14-19.

3. Arulselvi Subramanian, Kanchana Rangarajan, Sudeep Kumar, Kamran Farooque, Vijay Sharma, Mahesh Chandra Misra. Reviewing the blood ordering schedule for elective orthopaedic surgeries at a level one trauma care center. Journal of emergencies, trauma and shock. 2010; 3(3):225-230.

4. Olawumi Ho, Bolaji Bo. Blood utilization in elective surgical procedures in Ilorin. The Tropical Journal Of Health Sciences. 2006 ; 13:15-17.

5. Smallwood JA. Use of blood in elective general surgery: an area of wasted resources. BMJl. $1983 ; 286: 868-870$.

6. Guidelines for implementation of a maximum surgical blood order system schedule. The British committee for standards in haematology Blood Transfusion Task Force. Clin Lab Haematol. 1990 ; 12:321-7. 
7. Efraim K.Blood conservation in South Africa. A vital need .Bloodless Medicine and Surgery. $2001 ; 43: 7$.

8. Chawla T, Kakepoto GN, Khan MA. An audit of blood cross- match ordering practices at the Aga Khan University Hospital: First step towards a maximum surgical blood ordering schedule. J Pak Med Assoc. 2001 ; 51:251-4.

9. Vibhute M, Kamath SK, Shetty A. Blood utilization in elective general surgery cases: Requirements, ordering and transfusion practices. J Postgrad Med. 2000 ; 46:13-4.

10. Friedman BA, Oberdman HA, Chandnick AR, Kingdon KI. The maximum surgical Blood order schedule and surgical blood use in United States.Transfusion.1976; 16:380-7.

11. Friedman BA. An analysis of surgical Blood use in United States hospitals with application to the maximum surgical blood order schedule. Transfusion. 1979; 19:26878.

12. 12. Davis SP, Barrasso C, Ness PM. Maximizing the benefits of type and screen by continued surveillance of transfusion practice. Am J Med Technology. 1983 ; 49:579-82.

13. Sarma DP. Use of blood in elective surgery. JAMA. 1980 ; 243:1536-7.

14. Boral L, Henry JB. The type and screen: a safe alternative and supplement in selected surgical procedures. Transfusion.1977; 17:163.

15. Garratty G. The role of compatibility tests. In: Report of a meeting sponsored by the Bureau of Biologics for the Blood Products Advisory Committee. Transfusion. 1982; 22:169-72.

16. Dodsworth H, Dudley H. Increased efficiency of transfusion practice in routine surgery using pre-operative antibody screening and selective ordering with an abbreviated crossmatch.Br J Surg. 1985;72:102-104.

\section{ANALYSIS OF TRANSFUSION DATA IN ELECTIVE SURGERIES}

Table-1 :Shows blood usage from various surgical departments

\begin{tabular}{|l|l|l|l|l|l|l|l|l|}
\hline Department & $\begin{array}{l}\text { No.of } \\
\text { patients } \\
\text { cross } \\
\text { matched }\end{array}$ & $\begin{array}{l}\text { No. } \\
\text { of } \\
\text { units } \\
\text { cross } \\
\text { matc } \\
\text { hed }\end{array}$ & $\begin{array}{l}\text { No.of } \\
\text { patients } \\
\text { transfus } \\
\text { ed }\end{array}$ & $\begin{array}{l}\text { No. of } \\
\text { units } \\
\text { transfu } \\
\text { sed }\end{array}$ & C/T & $\%$ T & TI & MSBOS \\
\hline $\begin{array}{l}\text { 1.0BG\& } \\
\text { Gynaec }\end{array}$ & $488(61 \%)$ & 838 & 128 & 248 & 3.37 & 26 & 0.29 & 0.43 \\
2.Surgery & $112(14 \%)$ & 181 & 26 & 54 & 3.35 & 23 & 0.29 & 0.43 \\
3.Orthpaedics & $98(12 \%)$ & 105 & 24 & 28 & 3.75 & 24 & 0.26 & 0.39 \\
4.Urology & $80(10 \%)$ & 86 & 20 & 28 & 3.07 & 24 & 0.32 & 0.48 \\
\hline
\end{tabular}

Journal of Evolution of Medical and Dental Sciences/Volume1/Issue5/November-2012Page-657 


\begin{tabular}{|l|l|l|l|l|l|l|l|l|}
\hline \hline \multicolumn{1}{|l|}{$\begin{array}{l}\text { 5.Neurosurge } \\
\text { ry }\end{array}$} & $18(2 \%)$ & 50 & 15 & 41 & 1.2 & 83 & 2.27 & 3.4 \\
6.ENT & $8(1 \%)$ & 16 & Nil & Nil & Nil & Nil & Nil & Nil \\
Total & $\begin{array}{l}804 \\
(100 \%)\end{array}$ & 1276 & 213 & 399 & 2.015 & 26 & 0.31 & 0.465 \\
\hline
\end{tabular}

Table -2: Department of Obstretics and Gynaecology.

\begin{tabular}{|c|c|c|c|c|c|c|c|c|}
\hline Procedure & $\begin{array}{l}\text { No.of } \\
\text { patients } \\
\text { cross } \\
\text { matched } \\
\text { (Total= } \\
\text { ) }\end{array}$ & $\begin{array}{l}\text { No. of units } \\
\text { cross } \\
\text { matched } \\
\text { (Total= ) }\end{array}$ & $\begin{array}{l}\text { No. of } \\
\text { patients } \\
\text { transfused } \\
\text { (Total= ) }\end{array}$ & $\begin{array}{l}\text { No. of } \\
\text { units } \\
\text { Transfuse } \\
\text { d } \\
\text { (Total= ) }\end{array}$ & $\mathrm{C} / \mathrm{T}$ & $\begin{array}{l}\% \\
\mathrm{~T}\end{array}$ & $\mathrm{TI}$ & MSBOS \\
\hline 1.D\&C & 101 & 226 & 41 & 72 & 3.13 & 41 & 0.71 & 1 \\
\hline 2.TAHBS & 98 & 190 & 28 & 49 & 3.87 & 39 & 0.50 & 0.75 \\
\hline $\begin{array}{l}\text { 3.Vaginal } \\
\text { Hystrectomy }\end{array}$ & 28 & 36 & 07 & 12 & 2.33 & 25 & 0.42 & 0.6 \\
\hline $\begin{array}{l}\text { 4.Partial } \\
\text { Hystrectomy }\end{array}$ & 33 & 42 & 02 & 06 & 5.50 & 06 & 0.18 & 0.27 \\
\hline $\begin{array}{l}\text { 5.LSCS } \\
\text {-General }\end{array}$ & 190 & 272 & 28 & 46 & 4.13 & 15 & 0.24 & 0.36 \\
\hline $\begin{array}{l}\text {-Placenta } \\
\text { praevia }\end{array}$ & 38 & 72 & 22 & 63 & 0.60 & 58 & 1.65 & 2.47 \\
\hline
\end{tabular}

D\&C=Dilatation \& Curettage, TAHBS=Total abdominal hysterectomy and bilateral salphingooopherectomy, LSCS=Lower segment caesarean section 
Table-3: Department of General Surger

\begin{tabular}{|c|c|c|c|c|c|c|c|c|}
\hline Procedure & $\begin{array}{l}\text { No. of } \\
\text { patients } \\
\text { cross } \\
\text { matched }\end{array}$ & $\begin{array}{l}\text { No. of } \\
\text { units } \\
\text { cross } \\
\text { matched }\end{array}$ & $\begin{array}{l}\text { No. of } \\
\text { patients } \\
\text { transfused }\end{array}$ & $\begin{array}{l}\text { No. of } \\
\text { units } \\
\text { transfused }\end{array}$ & $\mathrm{C} / \mathrm{T}$ & $\% \mathrm{~T}$ & TI & MSBOS \\
\hline $\begin{array}{l}\text { 1.Open } \\
\text { Cholecystectomy }\end{array}$ & 06 & 14 & 01 & 02 & 07 & 33 & 0.3 & 0.45 \\
\hline $\begin{array}{l}\text { 2.Laproscopic } \\
\text { Cholecystectomy }\end{array}$ & 09 & 12 & Nil & Nil & 0 & 0 & 0 & 0 \\
\hline 3.Thyroidectomy & 08 & 09 & Nil & Nil & 0 & 0 & 0 & 0 \\
\hline $\begin{array}{l}\text { 4.Modified radical } \\
\text { mastectomy }\end{array}$ & 26 & 32 & 05 & 18 & 1.77 & 19 & 0.69 & 1.03 \\
\hline $\begin{array}{l}\text { 5.Right } \\
\text { hemicolectomy }\end{array}$ & 18 & 22 & 08 & 11 & 02 & 44 & 0.61 & 0.91 \\
\hline 6.0esophagectomy & 04 & 10 & Nil & Nil & 0 & 0 & 0 & 0 \\
\hline $\begin{array}{l}\text { 7.Large } \quad \text { bowel } \\
\text { resection }\end{array}$ & 12 & 30 & 03 & 14 & 2.14 & 25 & 1.16 & 1.74 \\
\hline 8.Spleenectomy & 12 & 22 & 05 & 05 & 4.4 & 41 & 0.41 & 0.61 \\
\hline $\begin{array}{l}\text { 9.Breast mass } \\
\text { lumpectomy }\end{array}$ & 07 & 12 & 02 & 02 & 06 & 17 & 0.28 & 0.42 \\
\hline 10.Hemorrhoidectomy & 10 & 18 & 02 & 02 & 09 & 05 & 0.2 & 0.3 \\
\hline
\end{tabular}


Table-4: Department of Orthopaedics

\begin{tabular}{|l|l|l|l|l|l|l|l|l|}
\hline Procedure & $\begin{array}{l}\text { No. of } \\
\text { patients } \\
\text { cross } \\
\text { matched }\end{array}$ & $\begin{array}{l}\text { No. of } \\
\text { units } \\
\text { cross } \\
\text { matched }\end{array}$ & $\begin{array}{l}\text { No. of } \\
\text { patients } \\
\text { transfused }\end{array}$ & $\begin{array}{l}\text { No. of } \\
\text { units } \\
\text { transfused }\end{array}$ & C/T & $\%$ T & TI & MSBOS \\
\hline $\begin{array}{l}\text { 1.Hemiarthroplasty } \\
2 . \text { Trochantric } \\
\text { fracture }\end{array}$ & 24 & 29 & 12 & 12 & 2.4 & 50 & 0.5 & 0.75 \\
$\begin{array}{l}\text { 3.Femur shaft } \\
\text { fracture }\end{array}$ & 18 & 11 & Nil & Nil & 02 & 0 & 0 & 0 \\
4.Disc surgery & 09 & 15 & 05 & 02 & 5.5 & 11 & 0.1 & 0.15 \\
5.Tibial fractures & 02 & 06 & 02 & 04 & 2.14 & 56 & 0.7 & 1.05 \\
$\begin{array}{l}\text { 6.Total hip } \\
\text { replacement }\end{array}$ & 04 & 07 & 03 & 03 & 1.5 & 100 & 02 & 3 \\
7.Shoulder repair & 18 & 12 & Nil & Nil & 0 & 0 & 0 & 0 \\
\hline
\end{tabular}

Table-5: Department of Urology

\begin{tabular}{|l|l|l|l|l|l|l|l|l|}
\hline Procedure & $\begin{array}{l}\text { No. of } \\
\text { patients } \\
\text { cross } \\
\text { matched }\end{array}$ & $\begin{array}{l}\text { No. of units } \\
\text { cross } \\
\text { matched }\end{array}$ & $\begin{array}{l}\text { No. of } \\
\text { patients } \\
\text { transfused }\end{array}$ & $\begin{array}{l}\text { No. of } \\
\text { units } \\
\text { transfused }\end{array}$ & C/T & \%T & TI & MSBOS \\
\hline 1.TURP & 41 & 41 & Nil & Nil & 0 & 0 & 0 & 0 \\
2.Nephrectomy & 04 & 06 & 04 & 06 & 1.0 & 100 & 1.5 & 2.25 \\
3.Urethroplasty & 12 & 06 & 03 & 04 & 1.5 & 25 & 0.3 & 0.45 \\
4.Radical \\
cystectomy
\end{tabular}

TURP $=$ Trans - urethral resection of prostate

Journal of Evolution of Medical and Dental Sciences/Volume1/Issue5/November-2012Page-660 
Table-6: Department of Neurosurgery

\begin{tabular}{|l|l|l|l|l|l|l|l|l|}
\hline Procedure & $\begin{array}{l}\text { No. of } \\
\text { patients } \\
\text { cross } \\
\text { matched }\end{array}$ & $\begin{array}{l}\text { No. of units } \\
\text { cross } \\
\text { matched }\end{array}$ & $\begin{array}{l}\text { No. of } \\
\text { patients } \\
\text { transfused }\end{array}$ & $\begin{array}{l}\text { No. of } \\
\text { units } \\
\text { transfused }\end{array}$ & C/T & $\%$ TI & MSBOS \\
\hline 1.Craniotomy & 18 & 50 & 15 & 41 & 1.2 & 83 & 2.27 & 3.4 \\
\hline
\end{tabular}

Table-7: Department of ENT

\begin{tabular}{|l|l|l|l|l|l|l|l|l|}
\hline Procedure & $\begin{array}{l}\text { No. of } \\
\text { patients } \\
\text { cross } \\
\text { matched }\end{array}$ & $\begin{array}{l}\text { No. of units } \\
\text { cross } \\
\text { matched }\end{array}$ & $\begin{array}{l}\text { No. of } \\
\text { patients } \\
\text { transfused }\end{array}$ & $\begin{array}{l}\text { No. of } \\
\text { units } \\
\text { transfused }\end{array}$ & C/T & $\%$ TI & MSBOS \\
\hline 1.Parotidectomy & 06 & 08 & Nil & Nil & 0 & 0 & 0 & 0 \\
2.Laryngectomy & 02 & 08 & Nil & Nil & 0 & 0 & 0 & 0 \\
\hline
\end{tabular}

